\title{
CLINICAL AND RADIOLOGICAL FINDINGS IN CERVICOCRANIAL ARTERY DISSECTION
}

\author{
Z. Betül YALCINER*, Göksel BAKAC TUMAY**, Sema DEMIRCI BRANDMEIER***, Melek KANDEMIR*, \\ Hayriye KUCUKOGLU****, Cengiz DAYAN ${ }^{* * * * *}$, Nurhak DEMIR ${ }^{* * * * * *}$ \\ *Bayindir Hospital Icerenkoy, Department of Neurology, Istanbul, TURKEY \\ **Kadikoy Florance Nightingale Hospital, Department of Neurology, Istanbul, TURKEY \\ ***Medical Faculty of Istanbul Medipol University, Department of Neurology, Istanbul, TURKEY \\ ****Bakirkoy Mazhar Osman State Training and Research Hospital for Psychiatric and Neurological \\ Diseases, $2^{\text {nd }}$ Clinic of Neurology, Istanbul, TURKEY \\ *****Bakirkoy Mazhar Osman State Training and Research Hospital for Psychiatric and Neurological \\ Diseases, $1^{\text {st }}$ Clinic of Neurology, Istanbul, TURKEY \\ ******Medical Faculty of Dokuz Eylul University, Department of Neurology, Izmir, TURKEY
}

\begin{abstract}
INTRODUCTION: Cervicocranial artery dissections account for $25 \%$ of ischaemic strokes in young adults. Numerous risk factors that can damage the structure of the vessel walls have been identified. Dissections can present with various forms of stroke, and are diagnosed using magnetic resonance angiography or digital subtraction angiography. In our study, we aimed to evaluate the clinical and radiological characteristics of cervicocranial artery dissections.

METHODS: We retrospectively analysed 45 patients, twenty-nine (64\%) males and 16 (36\%) females, pre-diagnosed with dissection in the Angiography Unit of the Bakirkoy Mazhar Osman State Training and Research Hospital for Psychiatric and Neurological Diseases. The mean age of females and males was 35 and 39 years, respectively.

RESULTS: Forty-one (91\%) patients presented with transient ischaemic attack and/or ischaemic stroke. Isolated 12th nerve paralysis was found in one patient, and headache was the only symptom in another. Digital subtraction angiography was performed in all the patients, and bilateral dissection was detected in six patients. From the angiography results, three different types of vessel pathologies were detected: 1- long-segment irregularities (65\%), 2- tapering occlusion (35\%) and 3- pseudoaneurysm (16\%). Radiological follow-up was done for 19 (42\%) patients; eight of them completely recovered showing normal imaging findings.

DISCUSSION and CONCLUSION: Dissection can present with a broad clinical spectrum, and it should be suspected in cases with unusual neck movement and mild-to-severe trauma. Digital subtraction angiography is still the best modality for the diagnosis of dissection

Keywords: Cervicocranial artery dissection, aetiology, imaging findings.
\end{abstract}

\section{SERVIKOKRANIYAL ARTER DISSKSIYYNLARINDA KLINIIK VE RADYOLOJIKK BULGULAR}

\section{ÖZET}

GíRIŞ ve AMAÇ: Servikokraniyal arter disseksiyonları genç erişkinlerdeki iskemik inmelerin \%25'inden sorumludur. Damar duvarı yapısına zarar veren çok sayıda risk faktörü tespit edilmiştir. Disseksiyonlar çeşitli inme formlarında görülebilirler ve manyetik rezonans anjiografi veya dijital substraksiyon anjiografi tetkikleri ile tanı konulabilir. Çalıșmamızda servikokraniyal arter disseksiyonlarının klinik ve radyolojik özelliklerinin değerlendirilmesi amaçlanmıştır. YÖNTEM ve GEREÇLER: Bakirkoy Mazhar Osman Ruh Sagligi ve Hastaliklari Egitim ve Arastirma Hastanesi anjiografi ünitesinde disseksiyon ön tanısı almış 45 hasta, 29 (\%64) erkek ve 16 (\%36) kadın, retrospektif olarak incelenmiştir. Ortalama yaş kadın ve erkeklerde sırasıyla 35 ve 39 idi.

BULGULAR: Hastaların 41'i (\%91) geçici iskemik atak ve/veya iskemik inme ile prezente olmuştur. İzole 12. kraniyal sinir felci bir hastada gözlenmiş, bir başkasında ise baş ağrısı tek semptom olarak görülmüştür. Tüm hastalara dijital substraksiyon anjiografi yapılmış ve 6 hastada bilateral disseksiyon saptanmıştır. Anjiografi sonuçlarında 3 farklı damar

Corresponding author: Melek Kandemir, MD. Bayindir Hospital Icerenkoy, Department of Neurology, Istanbul, Turkey.

Telephone: +9021657526 66-3373 E-mail: kandemirmelek@yahoo.com

$\begin{array}{ll}\text { Received: } 28.06 .2016 & \text { Accepted: 08.11.2016 }\end{array}$

This article should be cited as following: Yalciner Z.B, Bakac Tumay G, Demirci Brandmeier S, Kandemir M, Kucukoglu H, Dayan C, Demir N. Clinical and radiological findings in cervicocranial artery dissection. Turkish Journal of Cerebrovascular Diseases 2017; 23 (1): 10-16. doi:10.5505/tbdhd.2017.54366 
Yalciner et al.

patolojisi saptandı: 1- uzun segment düzensizlikleri (\%65) 2- kama şeklinde tıkanma (\%35) ve 3- yalancı anevrizma (\%16). Hastaların 19'u (\%42) radyolojik olarak takip edilebilmiş, bunlardan sekizinde radyolojik bulgular tamamen normale dönmüștür.

TARTIŞMA ve SONUÇ: Disseksiyon geniş bir klinik spektrumla prezente olabilir ve alıșılmışın dıșında boyun hareketi ve ılımlıdan şiddetliye kadar çeşitli düzeyde travma öyküsü olanlarda akla gelmelidir. Disseksiyon tanısında dijital substraksiyon anjiografisi hala en iyi yöntemdir.

Anahtar Sözcükler: Servikokraniyal arter diseksiyonları, etiyoloji, görüntüleme bulguları.

\section{INTRODUCTION}

Cervicocranial artery dissections (CCADs) account for $2 \%$ of all ischaemic strokes and $25 \%$ of the ischaemic strokes in young adults under the age of 45 years $(1,2,4,6,8-11,15,20,22,24-28$, $30-37)$. Although numerous risk factors that can damage the structure of the vessel walls have been identified, such as hypertension, smoking, hyperhomocysteinaemia, migraine, infection, hyperlipidaemia, alpha-1 antitrypsin deficiency, connective tissue disease (Ehlers-Danlos and Marfan syndromes, fibromuscular dysplasia, i.e., FMD) and trivial/minor trauma (such as chiropractic applications and hyperextension/flexion of neck), the reasons for CCAD and its pathogenesis still remain unclear (1, $7,10,15,17,26,28,29,32,34-36,38$ ).

Artery dissection starts with a rupture in the intimal layer in the weakest part of the vessel. Due to the high pressure in the vessel, the rupture extends into the tunica intima endothelial cells and media layer. The extension of the rupture along the vessel causes the formation of a cleavage and a false lumen, associated to it, resulting in stenosis and occlusion of the lumen. Thrombus formation in the dissection area is common; on the other hand, a sub-adventitial dissection can transform into a pseudoaneurysm $(6,10,20,22,27)$.

CCADs can present with completed stroke, transient ischaemic attack (TIA), subarachnoid haemorrhage (SAH), or isolated cranial nerve palsy $(1,9,30)$. Two possible mechanisms have been put forward for the development of stroke. The first is related to stenosis and occlusion of the real lumen, while the second is related to microemboli detached from the thrombus. If the dissection extends intracranially, the bleeding of the pseudoaneurysm may cause SAH. Further, the development of isolated cranial nerve palsies is associated with aneurysm compression or ischaemia $(6,10,20,22,27)$.

In this study, we aimed to evaluate the clinical and radiological characteristics of CCAD, which can appear in various forms.

\section{MATERIAL AND METHODS}

We retrospectively analysed the clinical and radiological characteristics of 45 patients prediagnosed with dissection between 1998 and 2004 in the Angiography Unit of Bakirkoy Mazhar Osman State Training and Research Hospital for Psychiatric and Neurological Diseases. Age, gender and risk factors of the patients were recorded. However, sufficient information was not obtained regarding the complaints and risk factors of eight patients. The images were taken in the cranial and cervical anterio-posterior, oblique and lateral planes using a digital subtraction angiography (DSA) Siemens Polystar device (Berlin, Germany). The findings were classified based on the anatomic region of the dissection. Nineteen patients were followed up, and DSA was performed in 12 of these patients. Further, control imaging with magnetic resonance angiography (MRA) was performed in 7 of the followed-up patients.

Our study is a retrospective analysis of the angiography results that were obtained for diagnostic purposes in the Angiography Unit. Therefore, we did not require study approval from the Ethical Board, although general consent was obtained from each hospitalized patient.

\section{RESULTS}

Of the 45 patients included in the study, 16 (36\%) were female and 29 (64\%) were male, with mean ages of 35.8 years (range, 19-69 years) and 39.6 years (range, 18-56 years), respectively. Table shows the risk factors, clinical presentations and imaging findings with respect to the dissection types. Eleven patients had a history of trivial/minör trauma (hyperextension/flexion/rotation of the neck, minor traffic accidents, or massage, etc.) 25 days prior to their complaint.

In $24(65 \%)$ of the 37 patients, there were complaints of headache and/or neck pain, correlating with the clinical findings, and these complaints were more common in the patients 
with vertebral artery dissections (VAD) compared to those with internal carotid artery dissections (ICAD).

Forty-one (91\%) patients presented with TIA and/or cerebrovascular accident in the form of ischaemic stroke. Six patients presented with TIA, six with ischaemic stroke development followed by TIA and 29 with completed ischaemic stroke. Furthermore, SAH was detected in one of the ischaemic stroke patients, and both SAH and VAD were detected in two patients overall.

Of the patients with DSA, 20 (44\%) had ICAD and $25(56 \%)$ had VAD. Bilateral dissection (Figure I) was present in six patients. In total, 55 vessel pathologies were detected, with more than one vessel affected in the same patient or more than one pathology detected in the same vessel in some patients. Three different types of vessel pathologies were detected: 1- long-segment irregularities (Figure II) 2- tapering occlusion (Figure II and III) 3-pseudoaneurysm (Figure IV).

In 36 (65\%) vessels, long-segment stenosis and irregularities were detected; further, occlusion and pseudoaneurysm were detected in 19 (35\%) and nine $(16 \%)$ vessels, respectively. The findings are summarized in Table.

Radiological follow-up was performed for 19 (42\%) patients. Eight patients showed normal radiological findings, (Figure V) with average follow-up period of 3.5 months (1-6 months), no recurrence was observed in any of the 19 patients.

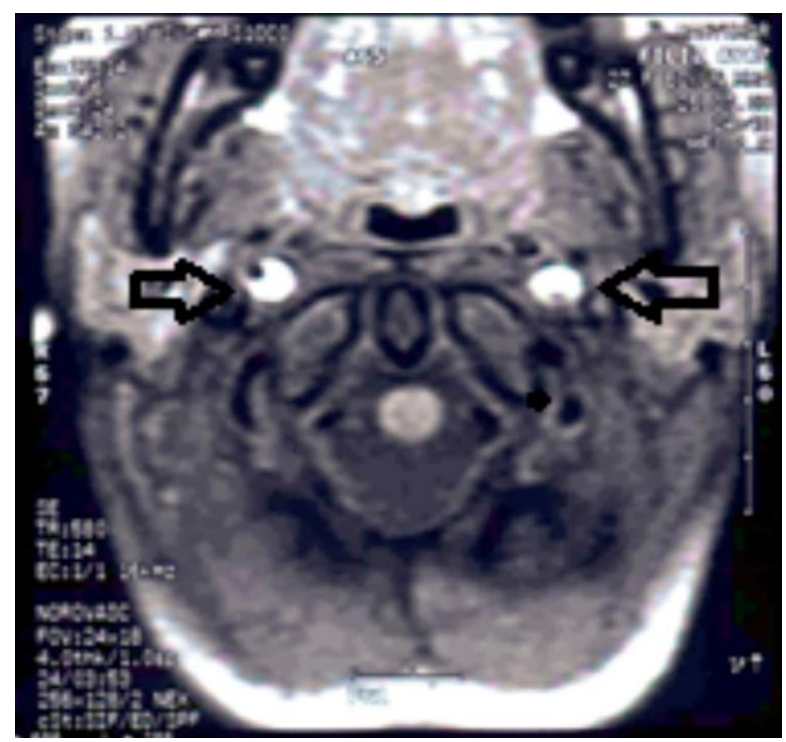

Figure I. Axial fat-saturated T1-weighted magnetic resonance imaging shows bilateral internal carotid artery dissections.

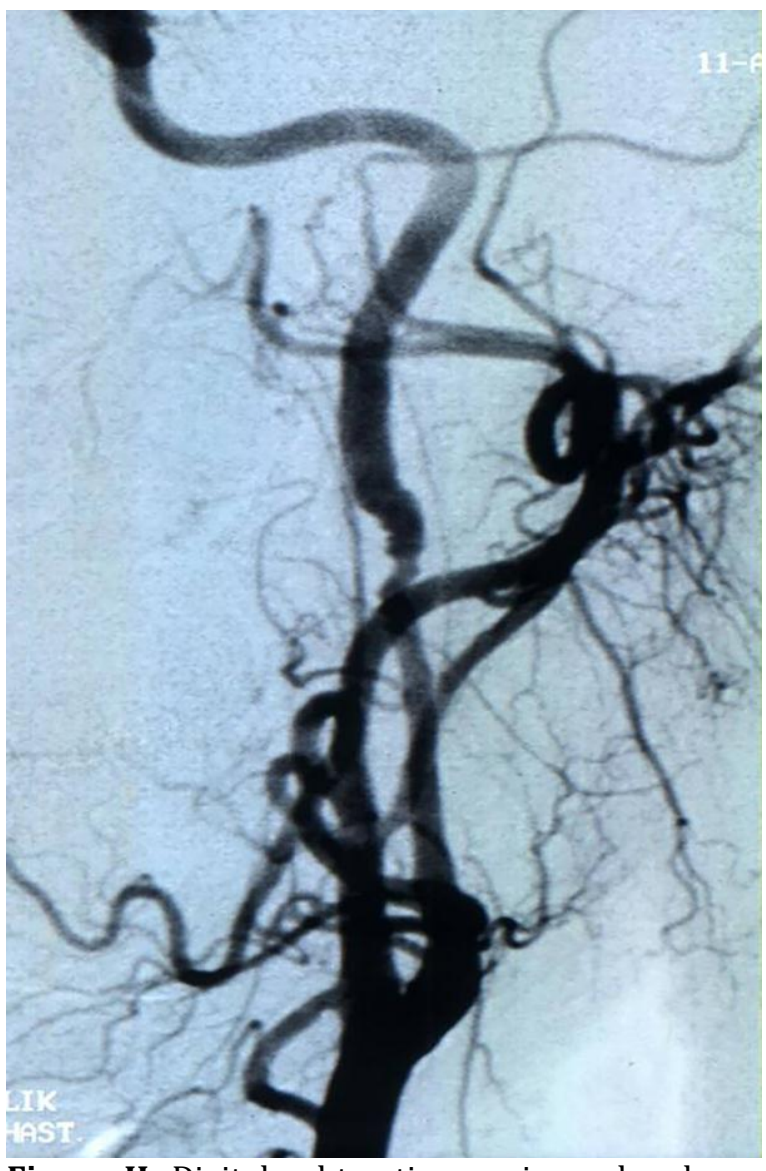

Figure II. Digital subtraction angiography shows long-segment irregularities in the carotid arteries (fibromuscular dysplasia).

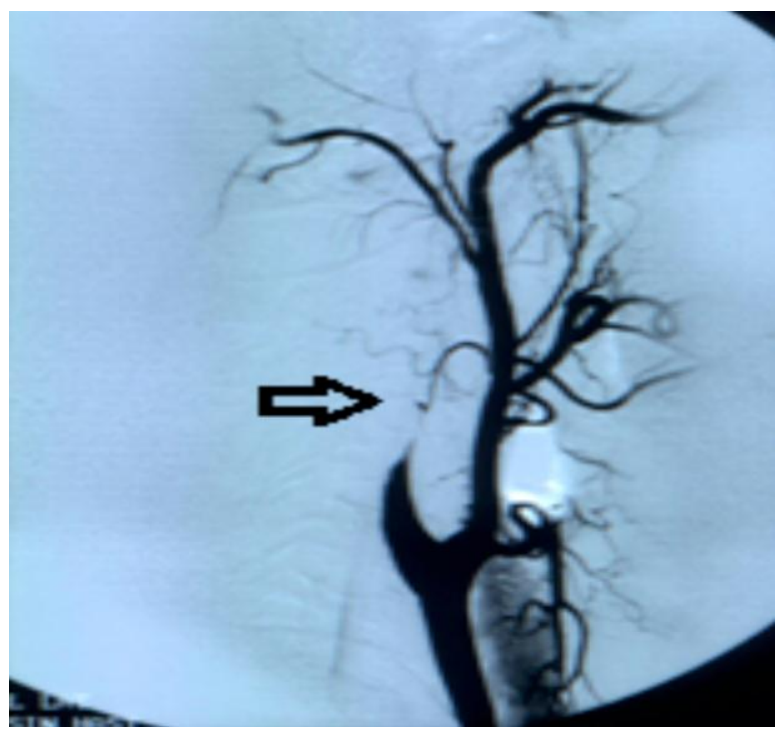

Figure III. Digital subtraction angiography shows tapering occlusion of the left carotid artery. 


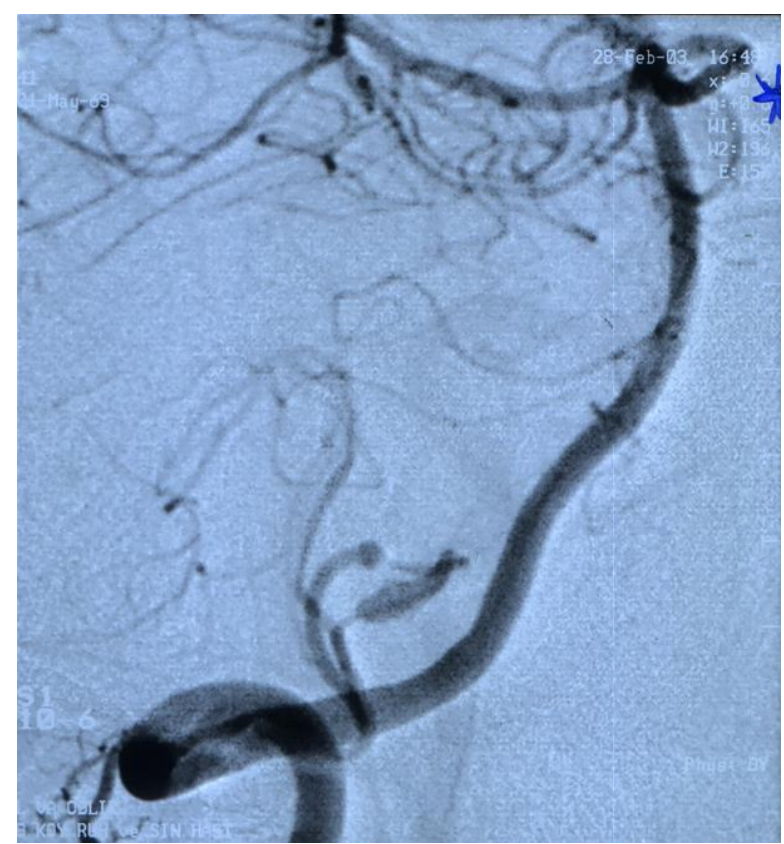

Figure IV. Digital subtraction angiography shows posterior inferior cerebellar artery dissection and pseudoaneurysm.

\section{DISCUSSION}

CCADs are one of the rare causes of stroke. Nevertheless, they are responsible for 10\%-25\% of the strokes seen in adults younger than 45 years of age $(1,2,4,6,8-11,15,20,22,24-28,30-37)$. In accordance, the average age of the patients in our study was under 40 years. Further, previous studies have shown that CCAD is more common in males than in females. In our study, the number of males was about twice that of females. Although there is no definite distinction among dissections in terms of gender, similar to the findings of previous studies, the females in our study were slightly younger than the males $(3,24,25,30)$. In some studies, it has been claimed that multiple vessel dissection is more common in females (3). However, in our study, they were more common in males.

Various risk factors have been identified for the aetiology of CCAD, including diseases related to connective tissue, environmental factors (infection), trivial/minor traumas and atherosclerotic risk factors $(1,7,10,15,17,26,28$, $29,32,34-36,38)$. The risk factors identified in our study were hypertension, hyperlipidaemia, migraine, smoking, alcoholism, FMD and trivial/minor trauma.
Table. Clinical and angiographic findings with respect to dissection types.

\begin{tabular}{|c|c|c|c|c|}
\hline & & $\begin{array}{l}\text { ICAD }^{*} \\
\text { (n) }\end{array}$ & $\begin{array}{l}\operatorname{VAD}^{\dagger} \\
\text { (n) }\end{array}$ & $\begin{array}{l}\text { Total } \\
\text { (n) }\end{array}$ \\
\hline \multicolumn{2}{|l|}{ Gender (M/F) } & $11 / 9$ & $18 / 7$ & 45 \\
\hline \multirow[t]{7}{*}{ Risk factors } & Smoking & 1 & 9 & 10 \\
\hline & Alcohol & 1 & 3 & 4 \\
\hline & Migraine & 3 & 4 & 7 \\
\hline & Hypertension & 0 & 5 & 5 \\
\hline & Hyperlipidaemia & 2 & 4 & 6 \\
\hline & Headache/Neck Pain & 9 & 15 & 24 \\
\hline & Minor Trauma & 3 & 8 & 11 \\
\hline \multirow{5}{*}{$\begin{array}{l}\text { Clinical } \\
\text { presentation }\end{array}$} & $\mathrm{TIA}^{\ddagger}$ & 5 & 1 & 6 \\
\hline & Stroke & 14 & 21 & 35 \\
\hline & $\mathrm{SAH}^{\S}$ & 0 & 2 & 2 \\
\hline & Isolated CNII XII Palsy & 1 & 0 & 1 \\
\hline & Headache (only) & 0 & 1 & 1 \\
\hline \multirow[t]{6}{*}{ DSA ${ }^{\pi}$ findings } & Extracranial Dissection & 24 & 22 & 46 \\
\hline & Intracranial Dissection & 19 & 13 & 9 \\
\hline & Bilateral Dissection & 4 & 2 & 6 \\
\hline & Long-Segment Irregularity & 15 & 12 & 27 \\
\hline & Tapering Occlusion & 9 & 10 & 19 \\
\hline & Pseudoaneurysm & 5 & 2 & 7 \\
\hline
\end{tabular}

Histories of massage, hyperextension/ flexion/rotation of the neck and minor traffic accidents were considered as trauma, up to 25days prior to the dissection. Twenty-four percent of the patients had a history of minor trauma. The frequency of minor trauma as a risk factor for CCAD has not been confirmed in the literature. However, a previous study showed a rate of minor trauma history of at least $40 \%$ in the 30-day period before CCAD (13). Severe trauma may directly result in vessel occlusion; on the other hand, it has been claimed that minor trauma can be a mechanical trigger, resulting in dissection only in the presence of an impairment that causes the vessel blood to become fragile on the ground $(13,17,21,29,34)$. Therefore, it has been suggested in some studies that mechanical triggers be used as risk factor rather than minor trauma $(13,17,29)$. However, in order to clarify the relationship between minor trauma and dissection, systematic studies involving large numbers of cases need to be conducted.

In our study, the most common complaints of the patients were headache and/or neck pain (65\%), and these complaints were more common in patients with VAD, similar to results of several other studies $(1,4,14,19)$. Headache was the only complaint of one of our patients with VAD. 


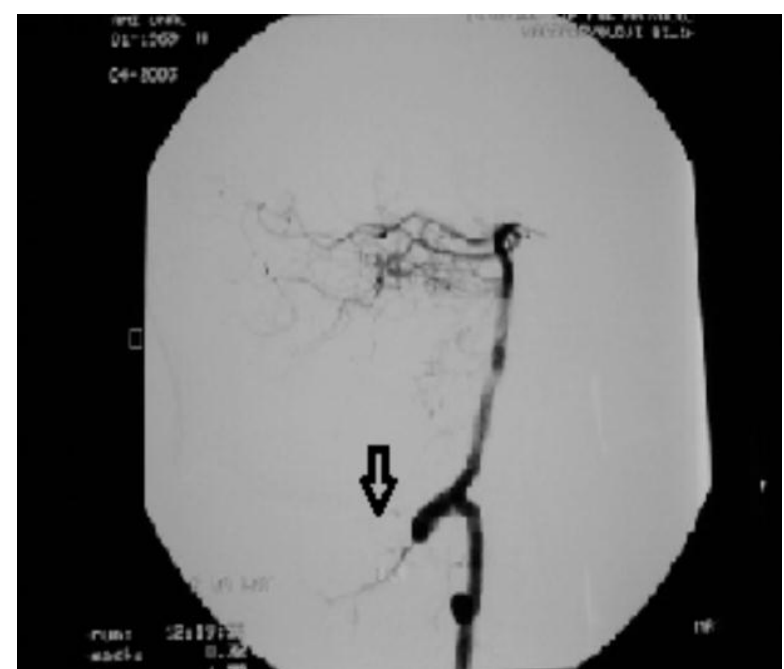

Figure V. One month later, spontaneous occlusion of posterior inferior cerebellar artery was observed in the same patient as that in Figure IV.

Dissection with isolated headache is reportedly rare; however, it is most commonly seen in patients with $\operatorname{VAD}(1,12,18)$. It has also been reported that pain could be unilateral or bilateral in dissections, even it is unilateral $(1,19)$.

Dissection can result in two situations depending on the localisation of the haematoma on the wall of the artery: 1) haematomas in the subintimal layer narrow the artery lumen and increase the risk of thrombosis, resulting in temporary or completed ischaemic stroke symptoms. 2) intramural haematomas settle subadventitially more frequently, causing the vessel wall to expand eccentrically. In these cases, as the haematoma gradually affects the artery lumen, cranial nerve involvement is observed rather than cerebral ischaemic findings $(6,10,16,20,22,27)$. Cranial nerve involvement is associated with ischaemia due to compression or interruption in the nourishing vessels of the nerve, and is seen in $10 \%$ of the extracranial carotid dissections $(9,21)$. In our study, there was one patient with isolated 12 th nerve involvement due to extracranial ICAD. If a sub-adventitially expanding dissection extends to the intracranial segment, it may also cause SAH. $\mathrm{SAH}$ is more common in intracranial dissections because there is no external elastic membrane in the adventitia layer of the intracranial arteries (30, 31). VAD presenting with SAH has been reported more often than CAD $(10,30)$. In our study, SAH was detected in three patients, one with stroke and the other two in association with VAD.
Although it is not useful for determining artery wall thickness and configuration in the diagnosis of the dissection, DSA is widely accepted as a gold standard imaging technique $(4,10,22$, $27,28,31,33,37$ ). As vertebral arteries (VAs) are smaller, deeper and with frequent anatomical variation and surrounding tissues, DSA is more useful in the diagnosis of $\operatorname{VAD}(1,22,31)$. Angiographic findings vary depending on the degree of luminal stenosis and the depth of the localized false lumen in the vessel wall (31). The 'string sign', which refers to the tapering of the eccentric stenosis that originates from the distal end of the carotid bulb, is the hallmark of ICADs. Focal stenoses in the distal part of dilatations are known as 'string and pearl signs'. Pathognomonic findings, such as double lumen or intimal flap are rarely observed $(10,21,33)$, and the most common findings in DSA, in descending order of frequency, are: irregular stenosis, occlusion and pseudoaneurysm. Pseudoaneurysm occurs if the dissection is sub-adventitial. If the pseudoaneurysm is thrombosed, it may not be visible initially $(27,37)$. Our findings, in the descending order of frequency, were irregular stenosis, occlusion and pseudoaneurysm. Fortyfour percent of our patients had ICAD and 56\% had VAD. Many previous studies have reported that ICADs are more common than VADs $(20,33)$. In a study by Maruyama et al., VADs were more common, similar to the findings of our study (23).

In recent years, non-invasive imaging modalities have gradually replaced DSA. However, DSA is still the best technique in cases where filiform stenosis with very slow blood-flow, FMD and complications of intracranial dissection need to be imaged, as well as in cases where noninvasive techniques fail to confirm the results. Doppler duplex ultrasound has low sensitivity in detecting VAD findings, which are especially difficult to distinguish from low-grade stenosis and deeper structures in the neck. MRA or computed tomography angiography, together with magnetic resonance imaging (MRI), play important roles in this differential diagnosis, and can be used to view haemorrhages associated with dissection and the ischaemic area. In MRI, the increased signal showing the narrowness of the eccentric lumen and the intramural haematoma (hyper intense image in $\mathrm{T} 1$ sequences) is a pathognomonic finding for $\operatorname{ICAD}(1,31,35)$ (Figure I). Due to the tissues surrounding VAs, the

Turkish Journal of Cerebrovascular Diseases 2017; 23 (1): 10-16 
detection of intramural haematomas in VAs depends on the affected artery segment. Therefore, MRI is more sensitive for diagnosing ICAD (31). In our study, 31 patients were subjected to MRI, and the findings were normal in seven of these patients. None of the patients were subjected to MRA for diagnostic purposes. Noninvasive methods are normally preferred in the follow-up for dissection $(20,33)$. In our study, we used DSA as the primary method for diagnostic imaging.

Dissection is a dynamic process, and stenosis can quickly develop into occlusion, or the opposite may happen, resulting in occlusion recanalization $(31,37)$. Although documentation of the follow-up of the dissection cases in previous studies was insufficient, in the cases that were followed up it has been reported that the majority of the occlusions were recanalised, while $46 \%$ of the pesudoaneurysms were permanent $(27,31)$. The recurrence rate is very low in dissections and is reported to be $2 \%$ for the first month and $1 \%$ after 1 year. Connective tissue disease, FMD and having a family history of dissection increase the likelihood of recurrence $(5,10,24,31,33)$. In our study, only 19 patients were followed up, and recurrence was not observed in any of them. There was complete recovery of vessel pathology, as observed by DSA or MRA, in eight patients.

Dissection is an important and curable cause of stroke in young adults. It can present with a broad clinical spectrum, from completed stroke to SAH, TIA, isolated headache, or cranial nerve involvement. In particular, patients with limited findings, such as isolated cranial nerve involvement and/or headache/neck pain must be carefully examined, along with other risk factors. Whether there has been a recent history of extraordinary neck movement or mild-to-severe trauma must also be ascertained. Additionally, dissection is a dynamic process and, consequently the findings may vary depending on the process and the imaging technique chosen. Therefore, to achieve definitive diagnosis, the most appropriate imaging modality must be chosen depending on the patient's overall clinical findings. We believe that despite being an invasive technique, DSA is still the best modality for the diagnosis of dissection.

Turkish Journal of Cerebrovascular Diseases 2017; 23 (1): 10-16

\section{REFERENCES}

1. Arnold M, Cumurciuc R, Stapf $C$, et al. Pain as the only symptom of cervical artery dissection. J Neurol Neurosurg Psychiatry 2006; 77: 1021-1024.

2. Arnold M, Bousser MG, Fahrni G, et al. Vertebral artery dissection: presenting findings and predictors of outcome. Stroke 2006; 37: 2499-2503.

3. Arnold M, Kappeler L, Georgiadis D, et al. Gender differences in spontaneous cervical artery dissection. Neurology 2006; 67: 1050-1052.

4. Auer A, Felber S, Schmidauer C, et al. Magnetic resonance angiographic and clinical features of extracranial vertebral artery dissection. J Neurol Neurosurg Psychiatry 1998; 64: 474-481.

5. Bassetti C, Carruzzo A, Sturzenegger M, et al. Recurrence of cervical artery dissection: A prospective study of 81 patients. Stroke 1996; 27: 1804-1807.

6. Benninger DH, Georgiadis D, Kremer C, et al. Mechanism of ischemic infarct in spontaneous carotid dissection. Stroke 2004; 35: 482-485.

7. Brandt T, Grond-Ginsbach C. Spontaneous cervical artery dissection: from risk factors toward pathogenesis. Stroke 2002; 33: 657-658.

8. Calvet D, Boutouyrie P, Touze E, et al. Increased stiffness of the carotid wall material in patients with spontaneous cervical artery dissection. Stroke 2004; 35: 2078-2082.

9. Campos CR, Massaro AR, Scaff M. Isolated oculomotor nerve palsy in spontaneous internal carotid artery dissection: case report. Arq Neuropsiquiatr 2003; 61: 668670.

10. Campos-Herrera CR, Scaff M, Yamamoto FI, et al. Spontaneous cervical artery dissection: an update on clinical and diagnostic aspects. Arq Neuropsiquiatr 2008; 66: 922-927.

11. Chaves C, Estol C, Esnaola MM, et al. Spontaneous intracranial internal carotid artery dissection: report of 10 patients. Arch Neurol 2002; 59: 977-981.

12. Divjak I, Slankamenac P, Jovićević M, et al. A case series of 22 patients with internal carotid artery dissection. Med Pregl 2011; 64: 575-578.

13. Engelter ST, Grond-Ginsbach C, Metso TM, et al. Cervical artery dissection: trauma and other potential mechanical trigger events. Neurology 2013; 80: 1950-1957.

14. Gottesman RF, Sharma P, Robinson KA, Arnan M, Tsui M, Ladha $\mathrm{K}$, et al. Clinical characteristics of symptomatic vertebral artery dissection: a systematic review. Neurologist 2012;18:245-54.

15. Guillon B, Berthet K, Benslamia L, et al. Infection and the risk of spontaneous cervical artery dissection: a casecontrol study. Stroke 2003; 34: e79-81.

16. Gulec F, Alper Y, Celebisoy N, et al. Isolated hypoglossal nerve palsy due to internal carotid artery dissection. J Neurol Sci (Turk) 2007; 24: 178-181.

17. Haynes MJ, Vincent K, Fischhoff $C$, et al. Assessing the risk of stroke from neck manipulation: a systematic review. Int J Clin Pract 2012; 66: 940-947.

18. Jatuzis D, Valaikiene J. Migraine-like presentation of vertebral artery dissection after cervical manipulative therapy. Perspectives in Medicine 2012; 1: 452-454.

19. Ju YE, Schwedt TJ. Abrupt-onset severe headaches. Semin Neurol 2010; 30: 192-200. 
20. Khanna K, Richard B. Pathophysiology and treatment of arterial dissection and stroke. Prog Neurol Psychiatry 2007; 11: 19-22.

21. Kuroda S, Abumiya T, Takahashi A, et al. Magnetic resonance findings in spontaneous dissection of the cervical internal carotid artery--case report. Neurol Med Chir (Tokyo) 1992; 32: 773-777.

22. Leclerc $X$, Lucas $C$, Godefroy 0 , et al. Preliminary experience using contrast-enhanced MR angiography to assess vertebral artery structure for the follow-up of suspected dissection. AJNR Am J Neuroradial 1999; 20: 1482-1490.

23. Maruyama H, Nagoya $H$, Kato $Y$, et al. Spontaneous cervicocephalic arterial dissection with headache and neck pain as the only symptom. J Headache Pain 2012; 13: 247 253.

24. Metso TM, Metso AJ, Salonen O, et al. Adult cervicocerebral artery dissection: a single-center study of 301 Finnish patients. Eur J Neurol 2009; 16: 656-661.

25. Metso AJ, Metso TM, Debette S, et al. Gender and cervical artery dissection. Eur J Neurol 2012; 19: 594-602.

26. Micheli S, Paciaroni M, Corea F, et al. Cervical artery dissection: emerging risk factors. Open Neurol J 2010; 4: 50-55.

27. Nedeltchev K, Bickel S, Arnold M, et al. R2-recanalization of spontaneous carotid artery dissection. Stroke 2009; 40: 499-504.

28. Nica C, Romanitan MO, Antochi F, et al. Vertebral artery dissection-clinical aspects. Romanian Journal of Neurology 2008; 7: 138-144.

29. Norris JW, Beletsky V, Nadareishvili Z. "Spontaneous" cervical arterial dissection. Stroke 2002; 33: 1945-1946.
30. Ohkuma H, Suzuki S, Ogane K. Study Group of the Association of Cerebrovascular Disease in Tohoku, Japan. Dissecting aneurysms of intracranial carotid circulation. Stroke 2002; 33: 941-947.

31. Pelkonen 0. Cervicocephalic artery dissection: radiological study with clinical outcome. 2004. Available from: http://herkules.oulu.fi/isbn9514272706.

32. Pride GL Jr, Replogle RE, Rappard G, et al. Stent-coil treatment of a distal internal carotid artery dissecting pseudoaneurysm on a redundant loop by use of a flexible, dedicated nitinol intracranial stent. AJNR Am J Neuroradiol 2004; 25: 333-337.

33. Rodallec MH, Marteau V, Gerber S, et al. Craniocervical arterial dissection: spectrum of imaging findings and differential diagnosis. Radiographics 2008; 28: 1711-1728.

34. Rubinstein SM, Peerdeman SM, van Tulder MW, et al. A systematic review of the risk factors for cervical artery dissection. Stroke 2005; 36: 1575-1580.

35. Schevink WI, Mokri B, O'Fallon WM. Recurrent spontaneous cervical-artery dissection. N Engl J Med 1994; 330: 393-397.

36. Thomas LC, Rivett DA, Attia JR, et al. Risk factors and clinical presentation of craniocervical arterial dissection: a prospective study. BMC Musculoskelet Disord 2012; 13: 164.

37. Touzé E, Randoux B, Méary E, et al. Aneurysmal forms of cervical artery dissection: associated factors and outcome. Stroke 2001; 32: 418-423.

38. Vila N, Millán M, Ferrer X, et al. Levels of $\alpha 1$-antitrypsin in plasma and risk of spontaneous cervical artery dissections: a case-control study. Stroke 2003; 34: E168169. 